\title{
Crop Evapotranspiration (ET) Estimation Models: A Review and Discussion of the Applicability and Limitations of ET Methods
}

\author{
Abhinaya Subedi ${ }^{1} \&$ José L. Chávez ${ }^{1}$ \\ ${ }^{1}$ Civil and Environmental Engineering Department, Colorado State University, Fort Collins, Colorado, USA \\ Correspondence: José L. Chávez, Civil and Environmental Engineering Department, Colorado State University, \\ 1372 Campus Delivery, Fort Collins, Colorado 80523-1372, USA. E-mail: jose.chavez@colostate.edu
}

Received: February 24, 2015 Accepted: April 10, 2015 Online Published: May 15, 2015

doi:10.5539/jas.v7n6p50 URL: http://dx.doi.org/10.5539/jas.v7n6p50

\begin{abstract}
This is a review paper on existing methodologies to calculate crop evapotranspiration $\left(\mathrm{ET}_{\mathrm{c}}\right)$. We have attempted to present all the important ET estimation procedures to date starting from the simple empirical Blaney Criddle method to the complex Shuttleworth model. The common approach to calculate $\mathrm{ET}_{\mathrm{c}}$ is to estimate a reference crop ET rate $\left(\mathrm{ET}_{\text {ref }}\right)$ using weather variables from nearby weather station, and multiplying it by an appropriate crop coefficient $\left(\mathrm{K}_{\mathrm{c}}\right)$. Recently, there have been attempts to calculate actual crop ET $\left(\mathrm{ET}_{\mathrm{a}}\right)$ directly without using $\mathrm{K}_{\mathrm{c}}$. The latter method is still in the developmental phase. This study reviews the existing literature on ET estimation and identifies research needs in the current methods and technology. The extension of the Shuttleworth model for hourly time step and the validity of the Irmak and Mutibwaa model at field level for various crops would be a good milestone for the one step ET estimation. Furthermore, there are indications that the development of a new variable canopy surface resistance $\left(r_{c}\right)$ model, which can be applicable for different crops at different climatic conditions, would be a good contribution in this field.
\end{abstract}

Keywords: $\mathrm{ET}_{\mathrm{c}}$ models applicability, crop evapotranspiration $\left(\mathrm{ET}_{\mathrm{c}}\right), \mathrm{ET}_{\mathrm{c}}$ models review, $\mathrm{ET}_{\mathrm{c}}$ models limitations

\section{Introduction}

Water is the basis of life. In the modern world, the demand of water is increasing because of the growing population as well as the increased urbanization and industrialization. As a result, water for agriculture is becoming limited. For this reason, accurate estimation of crop water requirement is very important. The problem of over irrigation or under irrigation will be minimized if we are able to accurately estimate crop water requirement or crop evapotranspiration $\left(\mathrm{ET}_{\mathrm{c}}, \mathrm{mm} / \mathrm{d}\right)$. The schematic diagram of the $\mathrm{ET}_{\mathrm{c}}$ process is shown in Figure 1. Various methods have been developed so far to estimate the $\mathrm{ET}_{\mathrm{c}}$. John Dalton (1766-1844) was the pioneer in developing an equation for evaporation from large water bodies, such as lakes and reservoirs. In his equation, the evaporation rate was calculated as the product of the vapor pressure deficit and a factor " $K$ " which is dependent on the wind speed. Since then, various ET methods have been developed, which are described in this article.

This paper reviews various $\mathrm{ET}_{\mathrm{c}}$ estimation models that have been developed to date. Among these models, the Penman Monteith (PM) equation is found to be more consistent over a wide range of climatic conditions (Allen et al., 2005). The most challenging part in the PM equation is to calculate the canopy surface resistance. The FAO 56 PM equation (Allen et al., 1998) and ASCE-EWRI (Environmental and Water Resources Institute of American Society of Civil Engineers) 2005 Standardized PM equation (ASCE-EWRI, 2005) are based on the fixed canopy surface resistance approach. These two methods calculate the reference crop ET, which along with the crop coefficient $\left(\mathrm{K}_{\mathrm{c}}\right)$ is used to calculate $\mathrm{ET}_{\mathrm{c}}$ or the actual crop ET (or $\mathrm{ET}_{\mathrm{a}}$ ). Recently, some researchers have pointed out flaws in this technique of estimating $\mathrm{ET}_{\mathrm{a}}$, so there have been attempts to calculate $\mathrm{ET}_{\mathrm{a}}$ directly using variable surface resistance values, without requiring crop coefficients. Katerji and Perrier (1983), Todorovic (1999), and Shuttleworth (2006) are notable researchers in variable surface resistance approach, which are described later in the manuscript. The subsequent sections describe different ET estimation techniques in a chronological order. 


\section{Evolution of Different Methods}

\subsection{Blaney-Criddle Method}

The Blaney-Criddle method was first developed in 1942. It is an empirical equation and very simple to use. They developed a simple mathematical model as given by Equation (1), (Blaney \& Criddle, 1962).

$$
\begin{gathered}
u=k f \\
U=\Sigma k f=K F
\end{gathered}
$$

where,

$\mathrm{u}=$ monthly consumptive use, in inches;

$\mathrm{f}=\mathrm{T}_{\mathrm{F}} \times \mathrm{p} / 100$ is the monthly consumptive use factor;

$\mathrm{T}_{\mathrm{F}}=$ mean monthly temperature, in degrees Fahrenheit $\left({ }^{\circ} \mathrm{F}\right)$;

$\mathrm{p}=$ monthly percentage of daytime hours of the year;

$\mathrm{k}=$ empirical consumptive use crop coefficient for monthly period;

$\mathrm{U}=$ seasonal consumptive use (or evapotranspiration), in inches;

$\mathrm{F}=$ sum of the monthly consumptive use factors for the period (sum of the products of mean monthly temperature and monthly percentage of daytime hours of the year);

$\mathrm{K}=$ empirical consumptive use crop coefficient for irrigation season or growing period.

In metric units,

where,

$$
u=k p\left(\frac{45.7 T_{a}+813}{100}\right)
$$

$\mathrm{u}=$ monthly consumptive use, in millimeters;

$\mathrm{T}_{\mathrm{a}}=$ mean monthly temperature, in degrees Centigrade/Celsius $\left({ }^{\circ} \mathrm{C}\right)$.

Although the method was originally developed to compute ET on a monthly basis, it can be modified to estimate daily values of ET with mean daily temperature (ASCE, 1990). As temperature methods tend to underestimate ET in arid regions while overestimating ET in humid regions, local calibration of the empirical coefficients is required to produce reliable estimates of ET (ASCE, 1990). The advantage of this method is the simplicity and disadvantage is that it underestimates ET grossly compared to the measured ET values (Sammis et al., 2011).

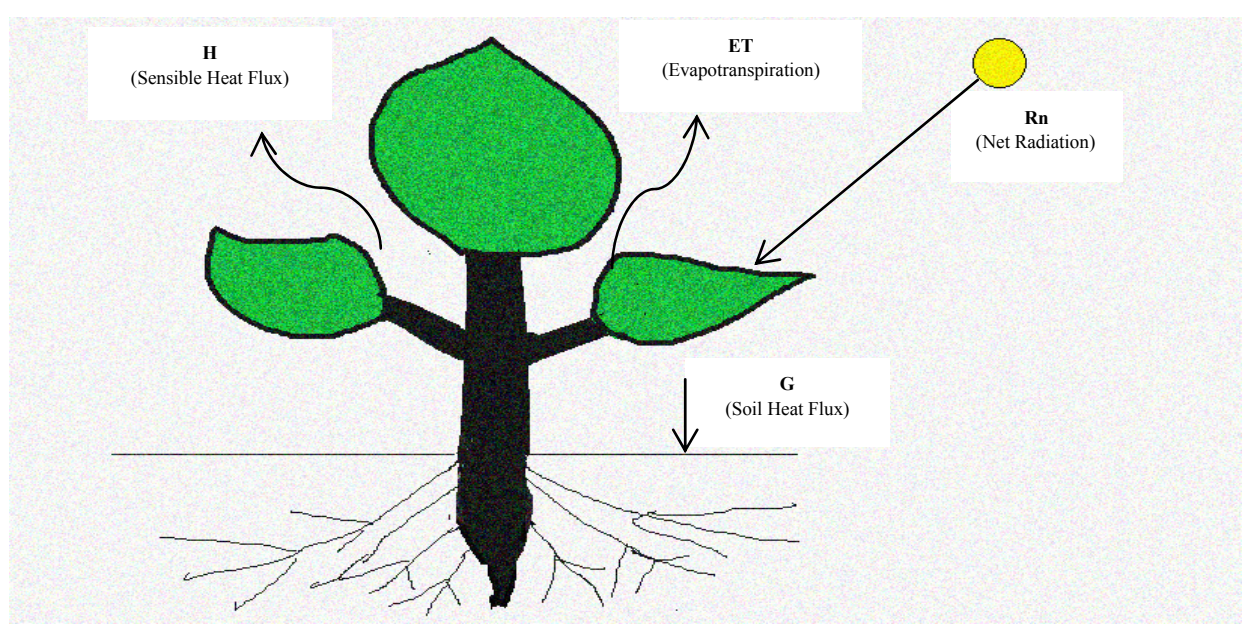

Figure 1. Schematic diagram of the ET process from a crop canopy

\subsection{Thornthwaite Method}

In 1948, Thornthwaite and Penman both developed potential evapotranspiration equation independently. Potential ET here refers to the maximum ET that can occur from a given crop surface. Penman's equation was more mechanistic while Thornthwaite's equation was more empirical. The Thornthwaite (1948) equation is 
simpler than Penman's equation because the method requires less climatic data. Thornthwaite's equation is as follows:

$$
P E T=16\left(10 T_{a} / I\right)^{a}
$$

where,

$\mathrm{PET}=$ potential evapotranspiration rate, in mm per month;

$\mathrm{T}_{\mathrm{a}}=$ mean monthly air temperature, in degrees Celsius $\left({ }^{\circ} \mathrm{C}\right)$;

$I$ = summation of the 12 monthly heat index $i$, where $i=\left(T_{a} / 5\right)^{1.514}$;

$\mathrm{a}=$ an empirical coefficient, which is calculated using the following equation:

$$
a=0.675 * 10^{-6} I^{3}-77.1 * 10^{-6} I^{2}+0.01792 I+0.49239
$$

This method is not based on strong mathematical and physical principles as it is purely empirical. However, as it is simple to use and gives acceptable result, in many parts of the world the method is still used to estimate irrigation water requirement.

Kumar et al. (1987) compared the Thornthwaite and Penman methods, in India, to calculate potential ET. They found that Penman's method seemed more realistic in estimating the mean annual potential evapotranspiration distribution over India. They also reported that Penman's potential evapotranspiration estimates were higher than Thornthwaite's estimates during the winter and pre-monsoon months and lower during the monsoon months, at most of the Indian stations. Pereira and De Camargo (1989) concluded that Thornthwaite's method was not appropriate for estimating ET in advective condition; however, they indicated that the method could be used for irrigation scheduling purposes when the fetch requirement is met. Bautista et al. (2009) concluded that Thornthwaite's method worked very well during the rainy months in both of their research sites; however, for drier months the use of Thornthwaite's method was not recommended without the adjustment of its coefficient " 16 ".

\subsection{Hargreaves Equation}

Hargreaves (1975) developed an equation for estimating ET which doesn't require wind speed data. His equation is as follows:

where,

$$
E T_{0}=0.0075 R_{s} T_{F}
$$

$\mathrm{ET}_{0}=$ potential $\mathrm{ET}$ for a grass reference surface in the same units as $\mathrm{R}_{\mathrm{s}}$;

$\mathrm{R}_{\mathrm{s}}=$ global solar radiation at the surface in equivalent water evaporation, usually mm of evaporation;

$\mathrm{T}_{\mathrm{F}}=$ mean air temperature in degrees Fahrenheit $\left({ }^{\circ} \mathrm{F}\right)$.

For degrees Celsius, the equation is modified as:

$$
E T_{0}=0.0135 R_{s}\left(T_{a}+17.8\right)
$$

Hargreaves (1977) developed the equation for $R_{s}$ as shown below. $R_{s}$ units as $R_{a}$ units:

$$
R_{s}=0.075 R_{a} S^{0.50}
$$

Hargreaves (1977) developed the equation for $\mathrm{S}$ to be applicable for Central America as:

$$
S=12.5(100-R H)^{0.50}
$$

where, $\mathrm{RH}=$ mean monthly relative humidity, $\%$.

Hargreaves and Samani (1982) developed an equation to determine $R_{s}$ from extraterrestrial radiation $\left(R_{a}\right)$ and the air temperature range (TD):

$$
R_{s}=K_{R S} R_{a} T D^{0.50}
$$

where, $R_{s}$ and $R_{a}$ are in the same units as indicated abvoe, $K_{R S}$ is a calibration coefficient and TD is mean maximum minus mean minimum daily temperatures, in degree Celsius, for a given period (generally one week).

Later on, Hargreaves and Samani (1985) obtained the following equation for $\mathrm{ET}_{0}$.

$$
E T_{0}=0.0022 R_{a}\left(T_{a}+17.8\right) T D^{0.50}
$$

For months of peak demand, Hargreaves and Samani (1985) recommended that the coefficient $(0.0022)$ be increased to 0.0023. ASCE-EWRI (2005) and Allen et al. (1998) recommended using Equation (11) when solar 
radiation, relative humidity and/or wind speed data are missing.

Hargreaves equation is also empirical, simple, and easy to use. Bautista et al. (2009), in a study, compared the results of the Hargreaves equation (Equation 11) with those of the FAO 56 PM equation (Allen et al., 1998), considering the latter equation as the standard method (reference). They found that the Hargreaves method compared well with the FAO 56 PM method with a resulting coefficient index (of determination) of 0.82 . However, the coefficient index improved to 0.91 after adjusting Hargreaves equation coefficient " 0.0022 " in Equation (11) from 0.0021 to 0.0024 (based on seasons) for tropical subhumid climate sites and from 0.0022 to 0.0026 for semiarid climate sites. Ravazzani et al. (2012) also compared the Hargreaves and Samani (1985) equation (HS) to FAO 56 PM equation for daily time steps in alpine river basins and found that the HS equation didn't perform well. The HS method showed overestimation of $\mathrm{ET}_{0}$ at lower elevation sites and underestimation at higher elevation sites. However, after using a correction factor, they found that the HS equation was in very good agreement with the FAO 56 PM equation.

\subsection{Christiansen Method}

Christiansen (1968) developed a simple method to estimate pan evaporation and crop evapotranspiration. According to Christiansen, the reasons for using pan evaporation data were: they were more consistent, already considerable work had been done to relate pan evaporation data with crop consumptive use and the pan evaporation data were readily available. The mathematical model that he developed was as follows:

$$
E=K R_{a} C
$$

where $\mathrm{E}$ is used in a general sense to apply to evaporation or evapotranspiration, $\mathrm{K}$ is a dimensionless constant developed empirically from data analysis, and $\mathrm{C}$ is a dimensionless coefficient related to climatic parameters, and $R_{a}$ is the extraterrestrial radiation, expressed as equivalent depth of evaporation in the same units as $E$. The coefficient $\mathrm{C}$ is expressed as the product of any number of subcoefficients that are functions of specific climatic parameters that are found to have a significant effect on the evaporation or evapotranspiration (Christiansen, 1968). Mathematically,

$$
C=C_{T} C_{W} C_{H} C_{S} C_{E}
$$

where, $\mathrm{C}_{\mathrm{T}}, \mathrm{C}_{\mathrm{W}}, \mathrm{C}_{\mathrm{H}}, \mathrm{C}_{\mathrm{S}}$ and $\mathrm{C}_{\mathrm{E}}$ represent the coefficients for air temperature, wind speed, relative humidity, sunshine percentage and elevation, respectively. The value of $\mathrm{K}$ was adjusted so that all coefficients were equal to unity for standard and approximate mean values of the parameter they represent (Christiansen, 1968). Christiansen (1968) described in detail how to calculate the different parameters in Equation (13) using Tables in his article.

This method is purely empirical as it is not based on any physical equation. This method can somehow accurately estimate ET on a monthly basis. However, this method cannot be used to calculate $\mathrm{ET}_{\mathrm{c}}$ on a daily basis or for shorter time steps. Wai et al. (2004) evaluated the performance of the Christiansen method and Penman methods with respect to the measured pan evaporation in Malaysia. They found that the Penman method ET results compared better than the Christiansen's method ET results to measured values (Pan) of potential evapotranspiration.

\subsection{Penman Related Equations}

\subsubsection{Original Penman Equation}

Penman (1948) developed a mechanistic approach to calculate ET. He used a combination approach by combining the surface energy balance equation with an aerodynamic equation. Several ET estimation models, for example, FAO 56 PM equation, ASCE-EWRI Standardized PM equation, CIMIS Penman method (as described in Temesgen et al., 2005) have been based on Penman equation. The original Penman equation is as follows:

$$
\begin{gathered}
E T=\frac{\left(\Delta\left(R_{n}-G\right)+k_{w}\left(e_{s}-e_{a}\right) f(u) \gamma\right)}{\lambda(\Delta+\gamma)} \\
\mathrm{f}(\mathrm{u})=\mathrm{a}_{\mathrm{w}}+\mathrm{b}_{\mathrm{w}} \mathrm{u}_{2} ;
\end{gathered}
$$

where,

$\mathrm{f}(\mathrm{u})=$ wind speed function

$\mathrm{k}_{\mathrm{w}}=$ unit coefficient $(6.43$ for ET in $\mathrm{mm} / \mathrm{d}$ or 0.268 for $\mathrm{ET}$ in $\mathrm{mm} / \mathrm{h}$ ).

Penman (1948) recommended the value of $a_{w}$ and $b_{w}$ as 1.0 and 0.537 , respectively, for clipped grass. Doorenbos 
and Pruitt (1977) in the FAO 24 paper recommended a constant of 6.61 in place of 6.43. They also recommended the values of $a_{w}$ and $b_{w}$ as 0.75 and 0.993 for full cover alfalfa. Wright (personal communication, 1987) as cited by Allen et al. (1989) derived an improved form of the Wright (1982) variable wind function by using the normal probability density function equation to approximate the change in $a_{w}$ and $b_{w}$ coefficients as a function of the Julian day (J) or day of the year for an alfalfa reference surface at Kimberly, Idaho. The equations for $a_{w}$ and $b_{w}$ are:

$$
\begin{gathered}
a_{w}=0.4+1.4 \exp \left[-\left(\frac{[J-173]}{58}\right)^{2}\right] \\
b_{w}=\left\{0.007+0.004 \exp \left[-\left(\frac{[J-243]}{80}\right)^{2}\right]\right\}(86.4)
\end{gathered}
$$

Equations (14) and (15), with $\mathrm{a}_{\mathrm{w}}$ and $\mathrm{b}_{\mathrm{w}}$ calculated with Equations (16) and (17) were termed 1982 Kimberly Penman equation by Allen et al. (1989).

Sun and Song (2008) evaluated the performance of the original Penman equation with measured ET values using the eddy covariance method for a marshland in Northeast China. They found that the Penman model overpredicted the mean measured ET for the growing season by 35\%. Yoder et al. (2005) compared ET estimations from eight different equations with measured lysimeter ET. Yoder et al. (2005) found that the FAO 56 PM equation performed better followed by the original Penman equation.

\subsubsection{CIMIS Penman Method}

The CIMIS Penman method calculates grass reference ET $\left(\mathrm{ET}_{0}\right)$ using the Penman combination equation, as modified by Pruitt and Doorenbos (1977), with a wind function that was developed at the University of California, Davis (Ventura et al., 1999 and Temesgen et al., 2005). The CIMIS Penman method uses $\mathrm{a}_{\mathrm{w}}=0.29$ and $b_{w}=0.53$ for $R_{n}>0$ and $a_{w}=1.14$ and $b_{w}=0.40$ for $R_{n} \leq 0$. These coefficients are applied hourly using Equation (14) where $\mathrm{ET}_{0}$ is in $\mathrm{mm} / \mathrm{h}, \mathrm{R}_{\mathrm{n}}$ is in $\mathrm{MJ} / \mathrm{m}^{2} / \mathrm{h}$ and $\mathrm{k}_{\mathrm{w}}=0.268$ (ASCE-EWRI, 2005). Temesgen et al. (2005) showed that the CIMIS Penman method correlated well with the FAO 56 PM equation for daily time step and with the ASCE Standardized equation (ASCE EWRI, 2005) for both daily and hourly time steps for 37 different studied sites in the state of California, USA. The limitation of this method is that this method may not be applicable in different climatic conditions as the coefficients were mainly developed for the climatic condition of California.

\subsubsection{Penman-Monteith Equation}

Monteith (1965) introduced some crop resistance terms in the original Penman equation and the equation later became the well-known "Penman-Monteith" (PM) ET equation. This equation is physically based and its robustness has been demonstrated as it does not require local calibrations, provided there are complete input data (Temesgen et al., 2005; Allen et al., 1999). This equation does not have any wind function; rather it has aerodynamic and surface resistance terms. The wind function in the Penman equation is calculated empirically whereas the aerodynamic and surface resistance terms are calculated using physically based and semi-empirical equations, respectively. Aerodynamic resistance $\left(r_{a}\right)$ is the resistance to molecular and turbulent diffusion of water vapor between leaf surfaces and the air above the canopy at a reference height (Robins, 1974). Surface resistance $\left(r_{c}\right)$ is the resistance to the diffusion of water vapor within the evaporating surface (Monteith et al., 1965). The popular reference ET equations like the FAO 56 PM equation and the ASCE Standardized Reference PM ET equations are also based on the Penman Monteith equation. Equation (18) is the so called Penman-Monteith (1965) equation:

$$
\lambda E=\frac{\left(\Delta\left(R_{n}-G\right)+\rho C_{p}\left(e_{s}-e_{a}\right) / r_{a}\right)}{\Delta+\gamma\left(1+r_{c} / r_{a}\right)}
$$

In the PM equation, all other parameters except $r_{c}$ are relatively straightforward to calculate. A procedure has been developed to calculate $r_{c}$ for grass and alfalfa surfaces. For this reason, to calculate the actual crop ET, the procedure is to first calculate the reference crop ET considering the grass or alfalfa as the reference crop surface and then multiplying the reference ET by the an appropriate crop coefficients. Direct use of the PM equation (Equation 18) to calculate actual crop ET (for any crop type_ is very rare in practice, although some researchers have tried this recently, which will be discussed in subsequent paragraphs. 


\subsection{Priestley Taylor Method}

Priestley and Taylor (1972) developed a semi-empirical equation to calculate potential evaporation ( $\lambda \mathrm{E}$ or ET), which is applicable for partial equilibrium condition. Their equation is as follows:

$$
\lambda E=\alpha \frac{\Delta\left(R_{n}-G\right)}{\Delta+\gamma}
$$

where $\alpha$ is a variable that can range from 1.15 to 1.50 depending on the surface type, climate and season. For water surfaces under condition of minimal advection, Priestley and Taylor (1972) approximated the value of $\alpha$ as 1.26. The value of $\alpha$ will be different for different crops and open water bodies. Researchers are still working on finding appropriate value of $\alpha$ for different surfaces. Hobbins et al. (2001) found the value of $\alpha$ as 1.3177 for vegetation while using a calibration subset of 92 basins. This method is more suitable to find the ET rate on a large scale which is more applicable in hydrology. The disadvantage of this method is that it is not applicable in advective condition. This method is simpler to use than the PM equation as it has less parameters and variables.

\subsection{Fixed Surface Resistance Approach}

Allen et al. (1998) developed guidelines for computing crop water requirements or $\mathrm{ET}_{\mathrm{c}}$, in the FAO $56 \mathrm{PM}$ paper. They recommended using the PM equation to calculate reference grass ET based on surface canopy resistance and aerodynamic resistance. They also tabulated the crop coefficient $\left(\mathrm{K}_{\mathrm{c}}\right)$ values for the initial, mid and end stages for various crops based on previous researchers' findings. The FAO 56 PM equation was modified mainly to calculate daily crop ET; however, the authors claimed that it can also be used to calculate hourly crop ET if the needed input hourly weather data are available. The FAO 56 PM method assumes a fixed surface resistance of $70 \mathrm{~s} / \mathrm{m}$ for the entire day or 24 hours. The fixed surface resistance value for 24 hours has been used for the daily or hourly FAO 56 PM equation.

In many parts of the world, including the US, alfalfa is used as another reference crop instead of clipped grass. Alfalfa can tolerate harsh weather conditions compared to the grass surface cover. Keeping this in mind, in 1999, the Irrigation Association (IA) requested the Evapotranspiration in Irrigation and Hydrology task Committee of the American Society of Civil Engineers (ASCE)-Environmental and Water Resources Institute (EWRI) to establish and define a benchmark reference evapotranspiration equation. Later, the ASCE EWRI ET task committee, in 2005, developed a reference evapotranspiration equation which is applicable for both tall (alfalfa) and short (grass) reference crops. As part of the standardization, the ASCE Penman-Monteith (ASCE-PM) equation and associated equations for calculating aerodynamic and bulk surface resistance have been combined and condensed into a single equation that is applicable to both surfaces (ASCE-EWRI, 2005). For the ASCE standardized PM equation, there is one fixed surface resistance for daytime and another fixed surface resistance for nighttime for each reference crop, hence this method is an improved version over the FAO 56 PM (Allen et al., 1998) equation.

\subsubsection{FAO 56 Penman-Monteith Equation}

The FAO 56 PM equation was based on the Penman-Monteith equation. The FAO 56 PM method defines the reference crop as a hypothetical crop with an assumed height of $0.12 \mathrm{~m}$ having a surface resistance of $70 \mathrm{~s} / \mathrm{m}$ and an albedo of 0.23 , closely resembling the evaporation of an extensive surface of green grass of uniform height, actively growing and adequately watered. Equation (18) can be approximated to Equation (20) after using the aerodynamic and surface resistance equations, which is the FAO 56 PM equation.

$$
E T_{0}=\frac{0.408 \Delta\left(R_{n}-G\right)+\left(\frac{\gamma 900}{T_{a}+273}\right) u_{2}\left(e_{s}-e_{a}\right)}{\left(\Delta+\gamma\left(1+0.34 u_{2}\right)\right.}
$$

where,

$\mathrm{ET}_{0}=$ grass reference $\mathrm{ET}(\mathrm{mm} / \mathrm{d}) ;$

$\mathrm{R}_{\mathrm{n}}=$ net radiation at the crop surface $\left(\mathrm{MJ} / \mathrm{m}^{2} / \mathrm{d}\right)$;

$\mathrm{G}=$ soil heat flux density $\left(\mathrm{MJ} / \mathrm{m}^{2} / \mathrm{d}\right)$.

The equations used for aerodynamic and surface resistances while deriving FAO 56 PM equation are as follows:

$$
r_{a}=\frac{\ln \left(\frac{z_{m}-d}{z_{o m}}\right) \ln \left(\frac{z_{h}-d}{z_{o h}}\right)}{k^{2} U_{z}}
$$


where $r_{a}$ is the aerodynamic resistance $(\mathrm{s} / \mathrm{m})$ for neutral atmospheric conditions, $z_{m}$ is height of wind speed measurements $(\mathrm{m}), \mathrm{z}_{\mathrm{h}}$ is height of humidity measurements $(\mathrm{m}), \mathrm{d}$ is zero plane displacement height $(\mathrm{m})=0.67 \mathrm{~h}_{\mathrm{c}}$, $\mathrm{h}_{\mathrm{c}}$ is the crop height $(\mathrm{m}), \mathrm{z}_{\mathrm{om}}=0.123 \mathrm{~h}_{\mathrm{c}}$ is the roughness length governing transfer of momentum $(\mathrm{m}), \mathrm{z}_{\mathrm{oh}}=0.1$ $\mathrm{z}_{\mathrm{om}}$ is the roughness length governing transfer of heat and water vapor $(\mathrm{m})$, (Allen et al., 1998), $\mathrm{k}$ is von-Karman's constant (taken as 0.41$)$, and $\mathrm{u}_{\mathrm{z}}$ is wind speed at height $\mathrm{z}(\mathrm{m} / \mathrm{s})$.

$$
r_{c}=\frac{r_{l}}{0.5 L A I}
$$

where $r_{c}$ is the canopy resistance $\left(\mathrm{s} \mathrm{m}^{-1}\right), r_{1}$ is the daily average stomatal resistance (which is assumed as $100 \mathrm{~s}$ $\mathrm{m}^{-1}$ for clipped grass and full cover alfalfa), and LAI is leaf area index $\left(\mathrm{m}^{2} / \mathrm{m}^{2}\right)$.

Lopez-Urrea et al. (2006) found that the FAO 56 PM equation performed better under semiarid climatic conditions of Albacete, Spain, as it agreed well with measured lysimeter ET compared to other versions of Penman equations and Hargreaves and Samani (1985) equation.

\subsubsection{ASCE-EWRI Standardized Penman Monteith Evapotranspiration Equation}

The ASCE Standardized Reference Evapotranspiration Equation (ASCE EWRI, 2005) is based on the Penman-Monteith equation, with some simplification and standardization on the aerodynamic and surface resistances. This equation is applicable for both tall (alfalfa) and short (grass) reference surfaces. A grass reference crop is defined as an extensive, uniform surface of dense, actively growing, cool-season grass with a height of $0.12 \mathrm{~m}$, and not short of soil water; whereas a full cover alfalfa reference crop is defined as an extensive, uniform surface of dense, actively growing alfalfa with a height of $0.50 \mathrm{~m}$, and not short of soil water (ASCE-EWRI, 2005). The equation is as follows:

$$
E T s z=\frac{0.408 \Delta\left(R_{n}-G\right)+\gamma C_{n} u_{2} \frac{e_{s}-e_{a}}{T_{a}+273}}{\Delta+\gamma\left(1+C_{d} U_{2}\right)}
$$

where,

$\mathrm{ET}_{\mathrm{sz}}=$ standardized reference crop evapotranspiration for short crop (grass) $\left(\mathrm{ET}_{\mathrm{os}}\right)$ or tall crop (alfalfa) $\left(\mathrm{ET}_{\mathrm{rs}}\right)$ surfaces ( $\mathrm{mm} / \mathrm{d}$ for daily time steps or $\mathrm{mm} / \mathrm{h}$ for hourly time steps);

$\mathrm{R}_{\mathrm{n}}=$ calculated net radiation at the crop surface $\left(\mathrm{MJ} / \mathrm{m}^{2} / \mathrm{d}\right.$ for daily time steps or $\mathrm{MJ} / \mathrm{m}^{2} / \mathrm{h}$ for hourly time steps); $\mathrm{G}=$ soil heat flux density at the soil surface $\left(\mathrm{MJ} / \mathrm{m}^{2} / \mathrm{d}\right.$ for daily time steps or $\mathrm{MJ} / \mathrm{m}^{2} / \mathrm{h}$ for hourly time steps).

The values for $C_{n}$ for the short and tall references are 900 and 1600, respectively, for the daily time steps whereas the $\mathrm{C}_{\mathrm{n}}$ are 37 and 66 for hourly time steps for both crops, respectively. Similarly the values for $\mathrm{C}_{\mathrm{d}}$ for the short and tall reference crops are 0.34 and 0.38 for daily time steps whereas the $C_{d}$ values for a short crop are 0.24 and 0.96 for daytime and for nighttime, respectively. For a the tall alfalfa reference crop, the $C_{d}$ values are 0.25 and 1.7 for daytime and nighttime, respectively. $\mathrm{C}_{\mathrm{n}}$ is a function of the time step and aerodynamic resistance whereas $C_{d}$ is a function of the time step, surface resistance and aerodynamic resistance (ASCE-EWRI, 2005).

Irmak et al. (2005) found a good correlation between the ASCE Standardized $\mathrm{ET}_{\mathrm{o}}$ equation results and the FAO $56 \mathrm{PM} \mathrm{ET}_{\mathrm{o}}$ resultscalculated on hourly time steps. However, the FAO $56 \mathrm{PM}$ method estimated 5\% to 8\% lower $\mathrm{ET}_{\mathrm{o}}$ compared to the ASCE Standardized $\mathrm{ET}_{0}$. According to Irmak et al. (2005) the results may be due to the higher surface resistance values during daytime periods in the FAO 56 PM equation. The authors also compared the daily $\mathrm{ET}_{\mathrm{o}}$ given by the ASCE Standardized daily $\mathrm{ET}_{\mathrm{o}}$ equation with the sum of the hourly $\mathrm{ET}_{\mathrm{o}}$ calculated using the ASCE Standardized hourly equation. They observed that the daily $\mathrm{ET}_{\mathrm{o}}$ values were generally higher than the sum of the hourly $\mathrm{ET}_{\mathrm{o}}$ and they recommended to use the hourly $\mathrm{ET}_{\mathrm{o}}$ values especially in advective condition.

\subsubsection{Valiantzas Model}

Valiantzas (2006) developed a set of equations to determine the $\mathrm{ET}_{\mathrm{o}}$ rate based on simplifications made to the Penman (1963) equation. His purpose was to enable ET computation with limited meteorological data. Valiantzas (2013a) then improved these equations and claimed that his model performed equivalent in accuracy to the Penman (1963) equation. His simplified equation to calculate grass reference ET is as follows:

$$
E T_{o} \approx 0.0393 R_{s} \sqrt{T_{a}+9.5}-0.19 R_{s}^{0.6} \varphi^{0.15}+0.048\left(T_{a}+20\right)\left(1-\frac{R H}{100}\right) u_{2}^{0.7}
$$

where, $\mathrm{ET}_{\mathrm{o}}$ is the grass reference ET $(\mathrm{mm} / \mathrm{d}), \mathrm{R}_{\mathrm{s}}$ is the measured or estimated incoming solar radiation $\left(\mathrm{MJ} / \mathrm{m}^{2} / \mathrm{d}\right)$, $\mathrm{T}_{\mathrm{a}}$ is the mean daily air temperature $\left({ }^{\circ} \mathrm{C}\right), \varphi$ is the latitude of the site (radians), $\mathrm{RH}$ is the relative humidity (\%) and $\mathrm{u}_{2}$ is the mean wind speed at $2 \mathrm{~m}$ height $(\mathrm{m} / \mathrm{s})$. He also developed an equation to calculate reference ET when the wind speed data is not available. The equation is as follows: 


$$
E T_{o} \approx 0.0393 R_{s} \sqrt{T_{a}+9.5}-0.19 R_{s}^{0.6} \varphi^{0.15}+0.078\left(T_{a}+20\right)\left(1-\frac{R H}{100}\right)
$$

Valiantzas (2013b) also developed a set of equations to calculate reference ET for arid and humid regions. His equation to calculate reference ET with two different aerodynamic term weighted factors is as follows:

$$
E T_{o} \approx 0.0393 R_{s} \sqrt{T_{a}+9.5}-2.4\left(\frac{R_{S}}{R_{a}}\right)^{2}-0.024\left(T_{a}+20\right)\left(1-\frac{R H}{100}\right)+W_{\text {aero }} 0.066\left(T_{a}+20\right)\left(1-\frac{R H}{100}\right) u^{0.6}
$$

where, $R_{a}$ is the extraterrestrial radiation $\left(\mathrm{MJ} / \mathrm{m}^{2} / \mathrm{d}\right)$ and $\mathrm{W}_{\text {aero }}$ is an empirical weighted factor. The value of $\mathrm{W}_{\text {aero }}$ is as follows:

$\mathrm{W}_{\text {aero }}=0.78$ when $\mathrm{RH}>65 \% ; \mathrm{W}_{\text {aero }}=1.067$ when $\mathrm{RH} \leq 65 \%$.

when the wind speed data is not available, the following equation applies:

$$
E T_{o} \approx 0.0393 R_{s} \sqrt{T_{a}+9.5}-2.4\left(\frac{R_{S}}{R_{a}}\right)^{2}+C_{u}\left(T_{a}+20\right)\left(1-\frac{R H}{100}\right)
$$

where, $\mathrm{C}_{\mathrm{u}}=0.054$ when $\mathrm{RH}>65 \%$ and 0.083 when $\mathrm{RH} \leq 65 \%$.

Valiantzas' model might be a good substitute when some weather data are missing. However, when there are good quality data available, the use of the mechanistic Penman-Monteith equation are more appropriate than the empirical methods.

\subsection{Variable Surface Resistance Approach}

All of the above mentioned equations, in section 2.7, calculate ET for a reference crop surface; which is either grass or alfalfa. In order to calculate the actual crop ET, the current practice is to multiply the reference crop ET with a crop coefficient $\left(\mathrm{K}_{\mathrm{c}}\right)$. Crop coefficients have been developed for different crop growth stages for various crops. However, Katerji and Rana (2006) have pointed out that the difference of $\pm 40 \%$ could be observed between the $\mathrm{K}_{\mathrm{c}}$ values reported by Allen et al. (1998) and the experimentally obtained $\mathrm{K}_{\mathrm{c}}$ values from different researchers. Based on findings from previous researchers (Rana et al., 1994; Steduto et al., 1996; Ventura et al., 1999; Lecina et al., 2003; Pereira, 2005; de Medeiros et al., 2006). Katerji and Rana (2006) indicated that there is up to $18 \%$ of underestimation and $13.4 \%$ of overestimation in $\mathrm{ET}_{\mathrm{o}}$ in semi-arid regions and humid regions, respectively, due to the use of fixed $r_{c}$ values. Hence, the cumulative error from reference ET calculation and the use of $\mathrm{K}_{\mathrm{c}}$ may be significant which could be a concern for irrigation water management purposes. In order to address this problem, some researchers have started to use variable surface resistance instead of fixed surface resistance to calculate actual crop ET directly without using the crop coefficient approach. This new approach is also called the one step crop ET estimation approach as there is no need of using the crop coefficients (a two-step approach). The variable surface resistance approaches that have been developed so far are discussed below:

\subsubsection{Jarvis Model}

Jarvis (1976) developed a multiplicative model to calculate stomatal resistance from weather parameters including air temperature, vapor pressure deficit, leaf water potential and ambient carbon dioxide $\left(\mathrm{CO}_{2}\right)$ concentration. However, the Penman-Monteith equation requires the bulk surface resistance and hence the knowledge of stomatal resistance only may not be enough to calculate ET. The upscaling of the stomatal resistance to the canopy level is required to calculate the bulk surface resistance. Alves and Pereira (1999) objected the methodology adopted by Jarvis, as they questioned the validity of the multiplicative model and also they expressed doubt in the assumption of weather parameters acting independently.

\subsubsection{Katerji and Perrier (KP) Model}

Katerji and Perrier (1983) found that a linear relationship can be established between the two ratios $r_{c} / r_{a}$ and $r^{*} / r_{a}$, where $r *$ is a climatic resistance term. They developed the following empirical relation:

$$
\frac{r_{c}}{r_{a}}=a \frac{r^{*}}{r_{a}}+b
$$

where, $\mathrm{a}$ and $\mathrm{b}$ are empirical calibration coefficients requiring experimental determination. The resistance, $\mathrm{r}^{*}$, is defined as:

$$
r^{*}=\frac{\Delta+\gamma}{\Delta \gamma} \frac{\rho c_{p} D}{R_{n}-G}
$$

where $\mathrm{D}$ is the vapor pressure deficit $(\mathrm{kPa})$, the units of $\mathrm{R}_{\mathrm{n}}$ and $\mathrm{G}$ are $\mathrm{W} / \mathrm{m}^{2}$.

Katerji and Rana (2006) reported that the coefficients a and $b$ have already been developed for alfalfa, rice, grass, lettuce, sweet sorghum, sunflower, grain sorghum, soybean, clementine orchard and sloping grassland. The 
coefficients have also been adapted for water stress conditions (Rana et al., 1997, 2001). Rana et al. (1997) claimed that the coefficients "a" and "b" have multi-local validity (i.e. they do not change with the site but only with the crop species).

The downside of this method is that there seems to be no physical meaning for these coefficients. In addition, the coefficients need to be tested for different crop species. Alves and Pereira (1999) indicated that Equation (28) is only valid for periods where the Bowen ratio varies between -0.3 and 0.3 .

\subsubsection{Todorovic Model}

Todorovic (1999) presented a mechanistic approach to calculate surface resistance using weather variables. His summarized methodology is as follows:

$$
t=\frac{\gamma}{\Delta} \frac{D}{(\Delta+\gamma)}
$$

Firstly, $\mathrm{t}$ which is the difference between actual canopy temperature and canopy temperature $\left({ }^{\circ} \mathrm{C}\right)$ in wet conditions is calculated using Equation (30). Then, using a quadratic Equation (31), X, which is the ratio of surface resistance $\left(r_{c}\right)$ to climatological resistance $\left(r_{i}\right)$, is calculated.

$$
X=\frac{a+\sqrt{b^{2}-4 a c}}{2 a}
$$

where,

$$
\begin{gathered}
a=\frac{\Delta+\gamma \Delta}{\Delta+\gamma} \gamma D \\
b=-\gamma Y t \\
c=-(\Delta+\gamma) t
\end{gathered}
$$

The climatological resistance $\left(\mathrm{r}_{\mathrm{i}}\right)$ can be calculated using:

$$
r_{i}=\frac{\rho c_{p} D}{\gamma\left(R_{n}-G\right)}
$$

In Equation (33), $\mathrm{Y}$ is the ratio of climatological resistance $\left(\mathrm{r}_{\mathrm{i}}\right)$ to aerodynamic resistance $\left(\mathrm{r}_{\mathrm{a}}\right)$. The units of all the resistances, which is the reciprocal of conductance, are in $\mathrm{s} / \mathrm{m}$. Rn and $\mathrm{G}$ in Equation (35) are in W/m .

Secondly, after finding $X, r_{c}$ is calculated by multiplying $X$ by $r_{i}$. The calculated $r_{c}$ will be inserted in the Penman-Monteith Equation (18) to calculate the actual crop ET. The actual crop ET can be defined as the rate of ET that occurs under field-environmental-surface condition which may depart from the ideal "standard" conditions.

Lecina et al. (2003) evaluated the KP and Todorovic models based on measured ET using lysimeter and eddy covariance systems. Based on their finding, they recommended to use the Todorovic model to calculate the hourly ET for semiarid windy conditions. Furthermore, Lecina et al. (2003) didn't find any improvement in ET estimates using the KP model. On the other hand, Shi et al. (2008) found that the KP model agreed better with the measured eddy covariance ET values for half-hourly and daily ET by summing the half-hourly ET values. They reported that the Todorovic model overestimated ET by about $30 \%$ in their experimental site in China.

\subsection{4 $\mathrm{Li}$ et al. Model}

Li et al. (2009) found some errors in the Todorovic model in the derivation of " $t$ ". Li et al. (2009) derived " $t$ " as:

$$
t=\frac{\gamma D C}{\Delta(\Delta+\gamma)}
$$

$\mathrm{Li}$ et al. proved that Todorovic's method missed the term $\mathrm{C}$ while deriving " $\mathrm{t}$ ". The missing parameter $\mathrm{C}$ was described as shown in Equation (37):

$$
C=\frac{\left(\frac{\Delta}{\gamma}\right) \cdot\left(\frac{1}{r_{i}}\right)+\frac{1}{r_{a}}}{\left(1+\frac{\gamma}{\Delta}\right)\left(\frac{1}{r_{c}}\right)+\left(\frac{\gamma}{\Delta}\right)\left(\frac{1}{r_{a}}\right)}
$$

In their article, $\mathrm{Li}$ et al. (2009) replaced $\mathrm{C}$ with $\left(1+\mathrm{D} / \mathrm{D}_{0}\right)$, where $\mathrm{D}_{0}$ is a parameter which accounts for the 
response of $t$ to vapor pressure deficit (D). They used $\mathrm{D}_{0}$ as $1.5 \mathrm{kPa}$ for their research, which they claimed was applicable for the winter wheat crop in the North China Plain. They also mentioned that the value of $\mathrm{D}_{0}$ can vary with crops and climatic conditions.

Li et al. (2009) showed that Todorovic model severely underestimated the canopy temperature and sensible heat flux and severely overestimated the latent heat flux. On the other hand, their model gave acceptable results for latent heat flux at both half-hourly and hourly time scales. The limitation of this method is that there there seems to be no physical meaning of $D_{o}$ and the value of $D_{0}$ is needed to compute " $t$ " and ultimately " $r_{c}$ ".

\subsubsection{Shuttleworth Model}

Shuttleworth (2006) introduced the concept of the crop independent blending height $(50 \mathrm{~m})$ to use as a reference height instead of $2 \mathrm{~m}$ reference height to enable the one step ET $\left(\mathrm{ET}_{\mathrm{a}}\right)$ calculation for different crops. Shuttleworth and Wallace (2009) used the existing PM equation and then calculated $r_{c}$ as a function of weather variables and $\mathrm{K}_{\mathrm{c}}$ values documented in FAO $56 \mathrm{PM}$ publication (Allen et al., 1998). They worked on a daily time step instead of hourly; hence their model is not applicable for hourly ET estimation. They concluded that the use of fixed crop coefficients $\left(\mathrm{K}_{\mathrm{c}}\right)$ to calculate actual crop ET can be problematic. The authors mentioned that the recommended $K_{c}$ values are said to be appropriate for wind speeds of $2 \mathrm{~m} / \mathrm{s}$ and "humid" conditions with $45 \%$ relative humidity. Whenever the weather conditions differ then the reported values of $\mathrm{K}_{\mathrm{c}}$ cannot provide reasonable estimates of ET. The authors also mentioned that the FAO 56 PM equation and the Priestley-Taylor equation with $\alpha=1.26$ give identical ET values in "humid" conditions. They showed from their Equation (11) that the ambient weather changes the value of the $\mathrm{K}_{\mathrm{c}}$ via the values of the climatological resistance and wind speed. They developed a relationship between $r_{c}$ and $K_{c}$ where $r_{c}$ was a function of $K_{c}, r_{s}{ }_{s}$ and $r_{s}{ }^{2}$, where $r_{s}{ }^{1}$ and $r_{s}^{2}$ could be calculated using their Equations (14) and (15) or performing interpolation from their Table 1 (See Appendix). The authors concluded that use of their approach will yield estimates of ET as good as those given by the FAO 56 PM model in humid conditions whereas it improves ET estimation for arid climates and for taller crops.

\subsubsection{Irmak and Mutibwaa Model}

Irmak et al. (2008) were able to upscale stomatal resistance (leaf scale) to the whole canopy surface resistance for maize using photosynthetic photon flux density (PPFD), leaf area index (LAI) for sunlit and shaded leaves, solar zenith angle, direct and diffuse solar radiation. They measured the stomatal resistance using porometers. They developed their model for corn and then successfully validated it for soybean with recalibration of some parameters (Irmak \& Mutiibwa, 2008; Irmak et al., 2008; Mutiibwa \& Irmak, 2010, 2012; Irmak et al., 2013). Irmak and Mutiibwa (2009) showed that the estimation of crop ET using the one step approach was better (an improvement) compared to the two step approach (i.e. using the reference crop ET multiplied by the crop coefficients). The one step approach ET was within 2 per cent of measured ET using the Bowen Ratio instrument whereas for the two step ET calculation, there was no distinct pattern of over or under estimation. On the other hand, the two step ET method underestimated actual ET (measured) especially when there was high evaporative demand according to the authors. This result suggests that the use of fixed surface resistance while calculating the reference ET is not appropriate (Irmak \& Mutibwaa, 2009).

Irmak and Mutibwaa (2009) were able to modify the Jarvis model, which they referred to as Modified-Jarvis-model (NMJ) and showed that their model is an improvement to the older version, as NMJ model improved the stomatal resistance estimation by $10 \%$ in RMSD (root mean square deviation) when compared to the measured stomatal resistance using a dynamic diffusion porometer. Irmak and Mutiibwa (2010) developed a set of empirical equations for nonstressed maize crop to calculate $r_{c}$ from weather variables. They used the measured ET from a Bowen Ratio instrument, then inverted the PM equation to back calculate $r_{\mathrm{c}}$. Then, they used a linear regression technique to find the relationship between $r_{c}$ and a set of weather variables. Irmak et al. (2013) also developed similar set of empirical equations for soybean crop to calculate $r_{c}$ from weather variables.

Table 1 below summarizes all the methods that have been discussed in the body of this article along with equations associated with those models. 
Table 1. Summary of equations of different ET estimation methods

\begin{tabular}{|c|c|c|}
\hline & Methods & Equations \\
\hline 1. & Blaney-Criddle (1942) & $u=k f$ \\
\hline 2. & Thornthwaite (1948) & $P E T=16\left(10 T_{a} / I\right)^{a}$ \\
\hline \multirow[t]{2}{*}{3.} & Hargreaves (1975) (for deg. F) & $E T_{0}=0.0075 R_{s} T_{F}$ \\
\hline & Hargreaves-Samani (1985), (deg. C) & $E T_{0}=0.0022 R_{s}\left(T_{a}+17.8\right) T D^{0.5}$ \\
\hline 4. & Christiansen (1968) & $E=K R_{a} C$ \\
\hline 5. & Penman Related Equations & \\
\hline \multirow[t]{2}{*}{5.1} & Original Penman Equation (1948) & $E T=\frac{\left(\Delta\left(R_{n}-G\right)+k_{w}\left(e_{s}-e_{a}\right) f(u) \gamma\right)}{\lambda(\Delta+\gamma)}$ \\
\hline & & $f(u)=a_{w}+b_{w} u_{2}$ \\
\hline 5.2 & CIMIS Penman Method & $\begin{array}{l}a_{w}=0.29, b_{w}=0.53 \text { for } R_{n}>0 \\
a_{w}=1.14, b_{w}=0.40 \text { for } R_{n} \leq 0\end{array}$ \\
\hline \multirow[t]{2}{*}{5.3} & Penman Monteith (1965) & $2.408 \Delta\left(R_{n}-G\right)+\left(\frac{\gamma 900}{T_{a}+273}\right) u_{2}\left(e_{s}-e_{a}\right)$ \\
\hline & & $\lambda E=\left(\Delta+\gamma\left(1+0.34 u_{2}\right)\right.$ \\
\hline 6. & Priestley Taylor (1972) & $\lambda E=\alpha \Delta(R n-G) /(\Delta+\gamma)$ \\
\hline
\end{tabular}

where $\alpha=1.26$ for water surfaces with minimum advection

7. Fixed Surface Resistance Approach

7.1 FAO 56 PM (1998)

$E T_{0}=\frac{0.408 \Delta\left(R_{n}-G\right)+\left(\frac{\gamma 900}{T_{a}+273}\right) u_{2}\left(e_{s}-e_{a}\right)}{\left(\Delta+\gamma\left(1+0.34 u_{2}\right)\right.}$

7.2 ASCE-EWRI Standardized PM Equation (2005)

$E T_{s z}=\frac{0.408 \Delta\left(R_{n}-G\right)+\gamma C_{n} u_{2} \frac{\left(e_{s}-e_{a}\right)}{T_{a}+273}}{\left(\Delta+\gamma\left(1+C_{d} u_{2}\right)\right.}$

7.3 Valiantzas Model (2006, 2013)

$E T_{o} \approx 0.0393 R_{s} \sqrt{T_{a}+9.5}-0.19 R_{s}^{0.6} \varphi^{0.15}+0.048\left(T_{a}+20\right)\left(1-\frac{R H}{100}\right) u^{0.7}$

8. Variable Surface Resistance Approach

8.1 Katerji-Perrier Model (1983)

$$
\begin{aligned}
& \frac{r_{c}}{r_{a}}=a \frac{r^{*}}{r_{a}}+b \\
& r^{*}=\frac{\Delta+\gamma}{\Delta \gamma} \frac{\rho c_{p} D}{R_{n}-G}
\end{aligned}
$$

8.2 Todorovic Model (1999)

$$
t=\frac{\gamma}{\Delta} \frac{D}{(\Delta+\gamma)}
$$

8.3 Li et al. Model (2009)

$$
\begin{aligned}
& t=\frac{\gamma D C}{\Delta(\Delta+\gamma)} \\
& C=\frac{\left(\frac{\Delta}{\gamma}\right) \cdot\left(\frac{1}{r_{i}}\right)+\frac{1}{r_{a}}}{\left(1+\frac{\gamma}{\Delta}\right)\left(\frac{1}{r_{c}}\right)+\left(\frac{\gamma}{\Delta}\right)\left(\frac{1}{r_{a}}\right)}
\end{aligned}
$$


Table 2. Advantages, limitations and application timestep of different ET estimation models

\begin{tabular}{|c|c|c|c|c|c|}
\hline & Methods & Variables Used & Advantages & Limitations & $\begin{array}{l}\text { Application } \\
\text { Timestep }\end{array}$ \\
\hline 1. & $\begin{array}{l}\text { Blaney-Criddle } \\
\text { Method (1942) }\end{array}$ & $\mathrm{T}_{\mathrm{a}}, \mathrm{T}_{\mathrm{F}}, \mathrm{p}, \mathrm{k}, \mathrm{K}$ & Simplicity & ET underestimation in general & Monthly \\
\hline 2. & $\begin{array}{l}\text { Thornthwaite } \\
\text { Method (1948) }\end{array}$ & $\mathrm{T}_{\mathrm{a}}$ & Simplicity & ET underestimation in advective condition & Monthly \\
\hline 3. & $\begin{array}{l}\text { Hargreaves and } \\
\text { Samani (1985) }\end{array}$ & $\mathrm{R}_{\mathrm{s}}, \mathrm{T}_{\mathrm{F}} \cdot \mathrm{T}_{\mathrm{a}}, \mathrm{R}_{\mathrm{a}}$ & Simplicity & $\begin{array}{l}\text { Problems of over and under estimation of } \\
\text { ET }\end{array}$ & Weekly \\
\hline 4. & $\begin{array}{l}\text { Christiansen Method } \\
\text { (1968) }\end{array}$ & $\mathrm{K}, \mathrm{R}_{\mathrm{a}}, \mathrm{C}$ & $\begin{array}{l}\text { More or less accurate to } \\
\text { predict ET for monthly } \\
\text { timestep }\end{array}$ & $\begin{array}{l}\text { Not accurate to calculate ET for daily or } \\
\text { shorter timesteps. }\end{array}$ & Monthly \\
\hline 5. & $\begin{array}{l}\text { Penman Related } \\
\text { Equations }\end{array}$ & & & & \\
\hline 5.1 & $\begin{array}{l}\text { Original Penman } \\
\text { Equation (1948) }\end{array}$ & $\begin{array}{l}\Delta, \mathrm{R}_{\mathrm{n}}, \mathrm{G}, \mathrm{e}_{\mathrm{s}}, \mathrm{ea} \\
\gamma, \mathrm{f}(\mathrm{u}), \lambda\end{array}$ & $\begin{array}{l}\text { Physical equation based on } \\
\text { the combination of surface } \\
\text { energy balance equation and } \\
\text { aerodynamic equation }\end{array}$ & $\begin{array}{l}\text { Wind speed function is difficult to obtain. } \\
\text { The equation was mainly developed for } \\
\text { evaporation from free water surfaces. }\end{array}$ & Daily, hourly \\
\hline 5.2 & $\begin{array}{l}\text { CIMIS Penman } \\
\text { Method }\end{array}$ & $\begin{array}{l}\Delta, \mathrm{R}_{\mathrm{n}}, \mathrm{G}, \mathrm{es}, \mathrm{e}_{\mathrm{a}} \\
\gamma, \mathrm{f}(\mathrm{u}), \lambda\end{array}$ & $\begin{array}{l}a_{w} \text { and } b_{w} \text { coefficients used in } \\
f(u) \text { are easy to obtain. Also } \\
\text { applicable for hourly } \\
\text { timesteps. }\end{array}$ & $\begin{array}{l}\text { The coefficients used in this equation were } \\
\text { developed for Californian condition, hence } \\
\text { may not be applicable elsewhere. }\end{array}$ & Hourly \\
\hline 5.3 & $\begin{array}{l}\text { Penman Monteith } \\
\text { equation (1965) }\end{array}$ & $\begin{array}{l}\Delta, \mathrm{R}_{\mathrm{n}}, \mathrm{G}, \mathrm{e}_{\mathrm{s}}, \mathrm{e}_{\mathrm{a}} \\
\gamma, \rho, \mathrm{c}_{\mathrm{p}}, \mathrm{r}_{\mathrm{a}}, \mathrm{r}_{\mathrm{c}}\end{array}$ & $\begin{array}{l}\text { Physical equation with the } \\
\text { inclusion of } r_{c} \text {. }\end{array}$ & $\begin{array}{l}\text { It is difficult to directly implement this } \\
\text { equation to calculate actual crop ET, as } r_{c} \text { is } \\
\text { difficult to obtain. }\end{array}$ & Daily, hourly \\
\hline 6. & $\begin{array}{l}\text { Priestley-Taylor } \\
\text { Method (1972) }\end{array}$ & $\alpha, \Delta, \gamma, \mathrm{R}_{\mathrm{n}}, \mathrm{G}$ & Relatively simple & $\begin{array}{l}\text { ET underestimation mainly in advective } \\
\text { condition. }\end{array}$ & Daily \\
\hline 7. & $\begin{array}{l}\text { Fixed Surface } \\
\text { Resistance Approach }\end{array}$ & & & & \\
\hline 7.1 & $\begin{array}{l}\text { FAO } 56 \text { PM } \\
\text { Equation (1998) }\end{array}$ & $\begin{array}{l}\Delta, \mathrm{R}_{\mathrm{n}}, \mathrm{G}, \mathrm{e}_{\mathrm{s}}, \mathrm{e}_{\mathrm{a}}, \\
\gamma, \mathrm{Ta}, \mathrm{u}_{2}\end{array}$ & $\begin{array}{l}\text { Considered very accurate to } \\
\text { calculate grass reference ET } \\
\text { on daily basis. }\end{array}$ & $\begin{array}{l}\text { May not be applicable to apply for hourly } \\
\text { timestep. }\end{array}$ & Daily \\
\hline 7.2 & $\begin{array}{l}\text { ASCE-EWRI } \\
\text { Standardized PM } \\
\text { Equation (2005) }\end{array}$ & $\begin{array}{l}\Delta, \mathrm{R}_{\mathrm{n}}, \mathrm{G}, \mathrm{e}_{\mathrm{s}}, \mathrm{e}_{\mathrm{a}} \\
\gamma, \mathrm{Ta}, \mathrm{u}_{2}\end{array}$ & $\begin{array}{l}\text { It can calculate both grass and } \\
\text { alfalfa reference crop ET on } \\
\text { both hourly and daily } \\
\text { timesteps. }\end{array}$ & $\begin{array}{l}\text { Kc needs to be developed also for alfalfa } \\
\text { reference surfaces. The use of fixed } r_{c} \text { for } \\
\text { entire day may induce some errors in } \\
\text { estimating reference ET. }\end{array}$ & Daily, hourly \\
\hline 7.3 & $\begin{array}{l}\text { Valiantzas Model } \\
(2006,2013)\end{array}$ & $\mathrm{T}, \mathrm{R}_{\mathrm{s}}, \varphi, \mathrm{RH}, \mathrm{u}_{2}$ & $\begin{array}{l}\text { Relatively simple, can be } \\
\text { used when some parameters } \\
\text { like wind speed is missing. }\end{array}$ & $\begin{array}{l}\text { It is semi-empirical, so may not be accurate } \\
\text { enough as PM equation. }\end{array}$ & Daily \\
\hline 8. & $\begin{array}{l}\text { Variable Surface } \\
\text { Resistance Approach }\end{array}$ & & & & \\
\hline 8.1 & Jarvis Model (1976) & & $\begin{array}{l}\text { New concept to calculate } \\
\text { stomatal resistance }\end{array}$ & $\begin{array}{l}\text { It is not easy to obtain canopy resistance }\left(r_{c}\right) \\
\text { from stomatal resistance. }\end{array}$ & \\
\hline 8.2 & $\begin{array}{l}\text { Katerji-Perrier } \\
\text { Model (1983) }\end{array}$ & $\begin{array}{l}\Delta, \mathrm{R}_{\mathrm{n}}, \mathrm{G}, \mathrm{e}_{\mathrm{s}}, \mathrm{e}_{\mathrm{a}} \\
\gamma, \mathrm{T}_{\mathrm{a}}, \mathrm{u}_{2,}, \mathrm{a}, \mathrm{b}, \mathrm{r}_{\mathrm{a}}\end{array}$ & $\begin{array}{l}\text { Relatively simple to calculate } \\
\text { actual crop ET in one step } \\
\text { process. }\end{array}$ & $\begin{array}{l}\text { This is empirical method. The coefficients } \\
\text { "a" and "b" need to be tested for different } \\
\text { species and also for different climatic } \\
\text { conditions. }\end{array}$ & Daily, hourly \\
\hline 8.3 & $\begin{array}{l}\text { Todorovic Model } \\
\text { (1999) }\end{array}$ & $\begin{array}{l}\Delta, \mathrm{R}_{\mathrm{n}}, \mathrm{G}, \mathrm{e}_{\mathrm{s}}, \mathrm{e}_{\mathrm{a}} \\
\gamma, \mathrm{T}_{\mathrm{a}}, \mathrm{u}_{2}, \mathrm{r}_{\mathrm{a}}\end{array}$ & $\begin{array}{l}\text { Mechanistic equation to } \\
\text { calculate } r_{c}\end{array}$ & $\begin{array}{l}\text { Some flaws in the procedure as shown by } \\
\text { Li et al. (2009). }\end{array}$ & Hourly \\
\hline 8.4 & $\begin{array}{l}\text { Li et al. Model } \\
\text { (2009) }\end{array}$ & $\begin{array}{l}\Delta, \mathrm{R}_{\mathrm{n}}, \mathrm{G}, \mathrm{e}_{\mathrm{s}}, \mathrm{e}_{\mathrm{a}} \\
\gamma, \mathrm{T}_{\mathrm{a}}, \mathrm{u}_{2}, \mathrm{r}_{\mathrm{a}}\end{array}$ & $\begin{array}{l}\text { Relatively simple to } \\
\text { implement. }\end{array}$ & $\begin{array}{l}\text { Only applicable for winter wheat crop in } \\
\text { North China Plain. }\end{array}$ & Hourly \\
\hline 8.5 & $\begin{array}{l}\text { Shuttleworth Model } \\
(2006,2009)\end{array}$ & $\begin{array}{l}\Delta, \mathrm{R}_{\mathrm{n}}, \mathrm{G}, \mathrm{e}_{\mathrm{s}}, \mathrm{e}_{\mathrm{a}} \\
\gamma, \mathrm{Ta}, \mathrm{u}_{2}, \mathrm{r}_{\mathrm{a}}, \mathrm{K}_{\mathrm{c}}\end{array}$ & $\begin{array}{l}\text { Provides one step ET for } \\
\text { daily timestep based by } \\
\text { calculating } r_{c} \text { based on } K_{c} \text {. }\end{array}$ & $\begin{array}{l}\text { Complicated to use, } r_{c} \text { is a function of FAO } \\
56 \text { Kc values, in other words, } r_{c} \text { depends on } \\
\text { the accuracy of } K_{c} \text {. }\end{array}$ & Daily \\
\hline 8.6 & $\begin{array}{l}\text { Irmak and Mutibwaa } \\
\text { Models }(2008,2009 \text {, } \\
2010,2013)\end{array}$ & PPFD, LAI & $\begin{array}{l}\text { Already implemented their } \\
\text { models successfully for corn } \\
\text { and soybean. }\end{array}$ & $\begin{array}{l}\text { Complicated to use. Needs many variables } \\
\text { to calculate } r_{c} \quad \text { including PPFD } \\
\text { (photosynthetic photon flux density). }\end{array}$ & Hourly \\
\hline
\end{tabular}




\section{Discussion}

Accurate estimation of crop ET is important and significant contributions from various researchers have been made until now. The full version Penman-Monteith equation is considered to be a robust method to calculate crop ET. However, it also has some limitations. The equation uses aerodynamic and surface resistance terms, where the aerodynamic resistance is relatively straight forward to calculate. However, the calculation of surface resistance is not easy. The use of the fixed surface resistance approach is a simplification of the true diurnal dynamics of this resistance, even for a reference crop under standard conditions. Hence, the modelling of the surface resistance would help in estimating crop ET with more accuracy.

Some authors (Lascano \& van Bavel, 2007; Lascano, Van Bavel, \& Evett, 2010; Paw, 1987, 1988, 1992; Tracy et al., 1984) point out that the exclusion of surface temperature while deriving the PM equation can induce some errors especially when the surface temperature and air temperature are significantly different. The other problem is with the linearity assumption of saturation vapor pressure and temperature curve. Lascano and Van Bavel (2007) and Lascano et al. (2010) calculated the surface temperature and ET simultaneously by iteration technique using fixed surface resistance (which they referred as the Recurvise Combination Method or RCM ET) and concluded that the RCM yielded ET rates very close to measured lysimeter ET values while the PM equation underestimated ET as much as $25 \%$. Paw $(1988,1991)$ developed a fourth order, third order and second order equations to solve the energy budget equation for latent heat flux, analytically. They claimed that these methods were superior compared to the PM method; as the error associated with the linearity assumption is corrected by using higher degree polynomials.

Some researchers (Dodds et al., 1997) highlighted that the use of the PM equation in advective condition would underestimate ET as the equation is not totally capable of incorporating the horizontal flow of sensible heat flux.

Shuttleworth and Wallace (1985) developed a two layer ET model, which could incorporate evaporation from the ground surfaces as well as the transpiration from the plant canopy. Their model is thus different from the Penman and Penman related equations which are basically a big leaf one layer ET model. Their model is more useful to calculate the ET rate from sparse canopy.

Regarding the one step ET estimation, KP model lacks physical meaning and it can only be applied when the Bowen ratio is between -0.3 and 0.3 (Alves and Pereira (2000), as cited by Lecina et al. (2003)). Also the coefficients used in the equation may vary among locations (Lecina et al., 2003). The Todorovic model (1999) is a mechanistic model to calculate surface resistance. However, Li et al. (2009) showed a missing term in his equation. Li et al., in their 2009 article, didn't try to use the improved Todorovic model, but instead used the simpler empirical relation to get the missing term, which was only applicable for winter wheat crop. The Shuttleworth model (2009) is an improved model of the existing method of two step ET estimation; however, the surface resistance used in his model is a function of the FAO 56 PM crop coefficient (Allen et al., 1998), which may not be accurately transferable to different environmental, crop and soil conditions. In addition, the Shuttleworth model is only applicable for daily time steps; thus, it may not work for hourly time steps. Irmak and Mutibwaa tried to upscale the surface resistance from the measured stomatal resistance; however, the method needs several field level data acquisition including the photosynthetic photon flux density, which is not easy to obtain.

\section{Future Work}

By reviewing the literature on ET estimation up-to-date, from various researchers, it is evident that still there is a need to further improve the estimation of reference as well as actual crop ET. The calculation of actual crop ET with the one step approach, which does not use crop coefficients, seems challenging but promising. However, if accomplished the error on the estimation of ET could be minimized using a (hourly) variable surface resistance. Supplementary, there has been some progress in calculating the surface resistance directly; in particular publications from Katerji and Perrier, Todorovic, Li et al, Shuttleworth, and Irmak and Mutibwaa. The extension of the Shuttleworth model for hourly time steps, to calculate $r_{c}$, could be an advancement to improve the ET estimation using the one step approach. Also, the validation of Irmak and Mutibwaa's model at field level, for various crops, could be another contribution. Finally, another alternative would be to develop a new $r_{c}$ model which would be robust enough to be applied to different crops under different climatic conditions.

\section{Acknowledgements}

The authors would like to acknowledge the funding agencies Colorado Agricultural Experiment Station, Colorado State University (CSU), and the USDA National Institute of Food and Agriculture (NIFA) for financially supporting this work. 


\section{References}

Allen, R. G., Jensen, M. E., Wright, J. L., \& Burman, R. D. (1989). Operational estimates of evapotranspiration. Agron. J., 81, 650-662. http://dx.doi.org/10.2134/agronj1989.00021962008100040019x

Allen, R. G., Periera, L. S., Raes, D., \& Smith, M. (1998). Crop evapotranspiration. Guidelines for computing crop water requirements (FAO Irrigation and Drainage Paper no. 56, p. 300). Rome.

Alves, I., \& Pereira, L. S. (1999). Modelling surface resistance from climatic variables? Agric. Water Manage, 42, 371-385. http://dx.doi.org/10.1016/S0378-3774(99)00041-4

American Society of Civil Engineers (ASCE). (1990). Evapotranspiration and Irrigation Water Requirements. Manuals and Reports on Engineering Practice (ASCE No. 70). New York.

ASCE-EWRI. (2005). The ASCE Standardized reference evapotranspiration equation. In R. G. Allen, I. A. Walter, R. Elliott, T. Howell, D. Itenfisu \& M. Jensen (Eds.), Environmental and Water Resources Institute (EWRI) of the American Society of Civil Engineers, ASCE, Standardization of Reference Evapotranspiration Task Committee Final Report (p. 213). Reston, VA: American Society of Civil Engineers (ASCE). Retrieved from http://ascelibrary.org/doi/abs/10.1061/40499(2000)126

Bautista, F., Bautista, D., \& Delgado-Carranza, C. (2009). Calibration of the equations of Hargreaves and Thornthwaite to estimate the potential evapotranspiration in semi-arid and subhumid tropical climates for regional applications. Atmosphera, 22(4), 331-348.

Blaney, H. F., \& Criddle, W. D. (1962). Determining consumptive use and irrigation water requirements. Agricultural Research Service Tech Bull 1275 (p. 59). U.S. Dept. Agr.

Christiansen, J. E. (1968). Pan evaporation and evapotranspiration from climatic data. J. Irrig. Drain. Div., 243-265.

De Medeiros, G. A., Arruda, F. B., \& Sakai, E. (2006). Crop coefficient for irrigated beans derived using three reference evaporation methods. Agric. Forest Meteorol., 135(1-4), 135-143. http://dx.doi.org/10.1016/j.agrformet.2005.11.010

Dodds, P. E., Meyer, W. S., \& Barton, A. (2005). A review of methods to estimate irrigated reference crop evapotranspiration across Australia. CRC for Irrigation Futures Technical Report No. 04/05.

Doorenbos, J., \& Pruitt, W. O. (1977). Crop water requirements. Irrig. and Drain. Paper No. 24. Rome, Italy: Food and Agric. Organization, United Nations.

Hargreaves, G. H. (1975). Moisture availability and crop production. Trans. ASAE, 18(5), 980-984. http://dx.doi.org/10.13031/2013.36722

Hargreaves, G. H. (1977). World water for agriculture. Agency for International Development, 177.

Hargreaves, G. H., \& Samani, Z. A. (1985). Reference crop evapotranspiration from temperature. Appl. Eng. Agric., 1(2), 96-99. http://dx.doi.org/10.13031/2013.26773

Hargreaves, G. L., Hargreaves, G. H., \& Riley, J. P. (1985). Irrigation water requirements for Senegal River Basin. J. Irrig. Drain. Eng., 111(3), 265-275. http://dx.doi.org/10.1061/(ASCE)0733-9437(1985)111:3(265)

Hobbins, M. T., Ramirez, J. A., \& Brown, T. C. (2001). The complimantary relationship in estimation of regional evapotranspiration: An enhanced Advection-Aridity model. Water Res. Res., 37(5), 1389-1403. http://dx.doi.org/10.1029/2000WR900358

Irmak, S., \& Mutiibwa, D. (2008). Dynamics of photosynthetic photon flux density and light extinction coefficient to assess radiant energy interactions for maize canopy. Transcations of the ASABE, 51(5), 1663-1673. http://dx.doi.org/10.13031/2013.25323

Irmak, S., \& Mutiibwa, D. (2009). On the dynamics of evaporative losses from Penman-Monteith with fixed and variable canopy resistance during partial and complete maize canopy. Transcations of the ASABE, 52(4), 1139-1153. http://dx.doi.org/10.13031/2013.27791

Irmak, S., \& Mutiibwa, D. (2010). On the dynamics of canopy resistance: Generalized linear estimation and relationships with primary micrometeorological variables. Water Resour. Res., 46, W008484. http://dx.doi.org/10.1029/2009WR008484

Irmak, S., Howell, T. A., Allen, R. G., Payero, J. O., \& Martin, D. L. (2005). Standardized ASCE Penman-Monteith: Impact of Sum-of-Hourly vs. 24-hour timestep computations at reference weather station sites. Transactions of the ASCE, 48(3), 1063-1077. http://dx.doi.org/10.13031/2013.18517 
Irmak, S., Mutiibwa, D., Irmak, A., Arkebauer, T. J., Weiss, A., Martin, D. L., \& Eisenhauer, D. E. (2008). On the scaling up leaf stomatal resistance to canopy resistance using photosynthetic flux density. Agric. And For. Meteorol., 148, 1034-1044. http://dx.doi.org/10.1016/j.agrformet.2008.02.001

Irmak, S., Mutiibwa, D., Payero, J., Marek, T., \& Porter, D. (2013). Modeling soybean canopy resistance from micrometeorological and plant variables for estimating evapotranspiration using one-step Penman-Monteith approach. Journal of Hydrology, 507, 1-18. http://dx.doi.org/10.1016/j.jhydrol.2013.10.008

Jarvis, P. G. (1976). The interpretations of the variations in leaf water potential and stomatal conductance found in canopies in the field. Philosophical Transcations of the Royal Society of London. Series B. Biological Sciences, 273(927), 593-610. http://dx.doi.org/10.1098/rstb.1976.0035

Katerji, N., \& Rana, G. (2006). Modelling evapotranspiration of six irrigated crops under Mediterranean climate conditions. Agric. Forest Meteorol., 138, 142-155. http://dx.doi.org/10.1016/j.agrformet.2006.04.006

Kumar, K. K., Kumar, K. R., \& Rakhecha, P. R. (1987). Comparison of Penman and Thornthwaite methods of estimating potential evapotranspiration for Indian conditions. Theor. Appl. Climatol., 38, 140-146. http://dx.doi.org/10.1007/BF00868097

Lascano, R. J., \& Van Bavel, C. H. M. (2007). Explicit and recursive calculation of potential and actual evapotranspiration. Agron. J., 99, 585-590. http://dx.doi.org/10.2134/agronj2006.0159

Lascano, R. J., Van Bavel, C. H. M., \& Evett, S. R. (2010). A field test of recursive calculation of crop evapotranspiration. Transactions of the ASABE, 53(4), 1117-1126. http://dx.doi.org/10.13031/2013.32601

Lecina, S., Martinez-Cob, A., Perez, P. J., Villalobos, F. G., \& Baselga, J. J. (2003). Fixed versus bulk canopy resistance for reference evapotranspiration estimation using the Penman-Monteith equation under semiarid conditions. Agric. Water Manage., 60, 181-198. http://dx.doi.org/10.1016/S0378-3774(02)00174-9

Li, L., Yu, Q., Su, Z., \& Tol, C. Van der. (2009). A Simple method using climatic variables to estimate canopy temperature, sensible and latent heat fluxes in a winter wheat field on the North China Plain. Hydrol. Process, 23, 665-674. http://dx.doi.org/10.1002/hyp.7166

Lopez-Urrea, R., Olalla, F. M. S., Fabeiro, C., \& Moratella, A. (2006). Testing evapotranspiration equations using lysimeter observations in a semiarid climate. Agricultural Water Mgmt., 85, 15-26. http://dx.doi.org/10.1016/j.agwat.2006.03.014

Monteith, J. L. (1965). Evaporation and environment. In G. E. Fogg (Ed.), Symposium of the Society for Experimental Biology: The State and Movement of Water in Living Organisms (Vol. 19, pp. 205-234). Academic Press, Inc., NY.

Monteith, J. L., Szeich, G., \& Waggoner, P. E. (1965). The measurement and control of stomatal resistance in the field. Journal of Applied Ecology, 2(2), 345-355. http://dx.doi.org/10.2307/2401484

Mutiibwa, D., \& Irmak, S. (2010). On the scaling up soybean leaf level stomatal resistance to canopy resistance for one-step estimation of actual evapotranspiration. Transactions of the ASABE, 54(1), 141-154. http://dx.doi.org/10.13031/2013.36269

Mutiibwa, D., \& Irmak, S. (2012). Transferability of Jarvis-type models developed and re-parameterized for maize to estimate stomatal resistance of soybean: analyses on model calibration, validation, performance, sensitivity and elasticity. Transcations of the ASABE, 56(2), 409-422. http://dx.doi.org/10.13031/2013.42688

Paw, U. K. T. (1987). Mathematical Analysis of the operative temperature and energy budget. J. Therm. Biol., 12(3), 227-233. http://dx.doi.org/10.1016/0306-4565(87)90009-X

Paw, U. K. T. (1992). A discussion of the Penman form equations and comparisons of some equations to estimate latent energy flux density. Agric. And Forest Meteorol., 57, 294-304. http://dx.doi.org/10.1016/0168-1923(92)90125-N

Paw, U. K. T., \& Gao, W. (1988). Applications of solutions to non-linear energy budget equations. Agric. And Forest Meteorol., 43, 121-145. http://dx.doi.org/10.1016/0168-1923(88)90087-1

Penman, H. L. (1948). Natural evaporation from open water, bare soil and grass. Proc. R. Soc. London, A 193, 120-146. http://dx.doi.org/10.1098/rspa.1948.0037

Penman, H. L. (1963). Vegetation and Hydrology. Technical Communication No. 53, Commonwealth Bureau of Soils. Harpenden, England. http://dx.doi.org/10.1097/00010694-196311000-00014 
Pereira, A. R. (2005). The Priestley Taylor parameter and the decoupling factor for estimating reference $\begin{array}{lllll}\text { evapotranspiration. } & \text { Agric. } & \text { Forest } & \text { Meteorol., } & 125,\end{array}$ http://dx.doi.org/10.1016/j.agrformet.2004.04.002

Pereira, A. R., \& De Camargo, A. P. (1989). An analysis of the criticism of Thornthwaite's equation for estimating potential evapotranspiration. Agric. and Forest Meteorol., 46, 149-157. http://dx.doi.org/10.1016/0168-1923(89)90118-4

Priestley, C. H. B., \& Taylor, R. J. (1972). On the assessment of surface heat flux and evaporation using large-scale parameters. Mon. Weather Rev., 100, 81-92. http://dx.doi.org/10.1175/1520-0493(1972)100\%3C 0081:OTAOSH\%3E2.3.CO;2

Rana, G., Katerji, N., \& Perniola, M. (2001). Evapotranspiration of sweet sorghum: A general model and multilocal validity in semiarid environmental conditions. Water Res. Research, 37(12), 3237-3246. http://dx.doi.org/10.1029/2001WR000476

Rana, G., Katerji, N., Mastorilli, M., \& El-Moujabber, M. (1994). Evapotranspiration and canopy resistance of grass in a Mediterranean region. Theor. Appl. Climatol., 50, 61-71. http://dx.doi.org/10.1007/BF00864903

Rana, G., Katerji, N., Mastorilli, M., \& El-Moujabber, M. (1997). A model for predicting actual evapotranspiration and canopy resistance of grass in a Mediterranean region. Theor. And App. Climatology, 56(1-2), 45-55. http://dx.doi.org/10.1007/BF00863782

Ravazzani, G., Corbari, C., Morella, S., Gianoli, P., \& Mancini, M. (2012). Modified Hargreaves-Samani equation for the assessment of reference evapotranspiration in alpine river basins. J. Irrig. Drain. Engrg., 138(7), 592-599. http://dx.doi.org/10.1061/(ASCE)IR.1943-4774.0000453

Robins, P. C. (1974). A method of measuring the aerodynamic resistance to the transport of water vapor from forest canopies. Journal of Applied Ecology, 11(1), 315-325. http://dx.doi.org/10.2307/2402024

Sammis, T. W., Wang, J., \& Miller, D. R. (2011). The transition of the Blaney-Criddle formula to the Penman-Monteith equation in the Western United States. Journal of Service Climatology, 5(1), 1-11.

Shi, T., Guan, D., Wang, A., Wu, J., Jin, C., \& Ham, S. (2008). Comparison of three models to estimate evapotranspiration for a temperate mixed forest. Hydrological Processes, 22, 3431-3443. http://dx.doi.org/10.1002/hyp.6922

Shook, K., \& Gray, D. M. (1997). Snowmelt resulting from advection. Hydrological Processes, 11, 1725-1736. http://dx.doi.org/10.1002/(SICI)1099-1085(19971030)11:13<1725::AID-HYP601>3.0.CO;2-P

Shuttleworth, W. J. (2006). Towards one-step estimation of crop water requirements. Transactions of the ASABE, 49(4), 925-935. http://dx.doi.org/10.13031/2013.21738

Shuttleworth, W. J., \& Wallace, J. S. (1985). Evaporation from sparse crops - An energy combination theory. $Q$. J. R. Meteorol. Soc., 111, 839-855. http://dx.doi.org/10.1002/qj.49711146910

Shuttleworth, W. J., \& Wallace, J. S. (2009). Calculating the water requirements of irrigated crops in Australia using the Matt-Shuttleworth approach. Transactions of the ASABE, 52(6), 1895-1906. http://dx.doi.org/10.13031/2013.29217

Steduto, P., Caliandro, A., Rubino, P., Mechlia, N. B., Masmoudi, M., Martinez-Cob, A., ... Faci, M. J. (1996). Penman-Monteith reference evapotranspiration estimates in the Mediterranean region. In C. R. Camp, E. J. Sadler \& R. E. Yoder (Eds.), Proceedings of the International conference on evapotranspiration and irrigation scheduling (pp. 357-364). San Antonio, TX.

Temesgen, B., Eching, S., Davidoff, B., \& Frame, K. (2005). Comparison of some reference evapotranspiration equations for California. J. Irrig. Drain. Engrg., 131, 1(73). http://dx.doi.org/10.1061/(ASCE)0733-9437(2005)131:1(73)

Thornthwaite, C. W. (1948). An approach towards a rational classification of climate. Geogr. Rev., 38, 55-94. http://dx.doi.org/10.2307/210739

Todorovic, M. (1999). Single-layer evapotranspiration model with variable canopy resistance. J. Irrig. and Drain. Engrg., 125(5), 235-245. http://dx.doi.org/10.1061/(ASCE)0733-9437(1999)125:5(235)

Tracy, C. R., Berkum, F. H. V., Tsuji, J. S., Stevenson, R. D., Nelson, J. A., Barnes, B. M., \& Huey, R. B. (1984). Errors resulting from linear approximations in energy balance equations. J. Therm. Biol., 9(4), 261-264. http://dx.doi.org/10.1016/0306-4565(84)90006-8 
Valiantzas, J. D. (2006). Simplified versions for the Penman evaporation equation using routine weather data. Journal of Hydrology, 331, 690-702. http://dx.doi.org/10.1016/j.jhydrol.2006.06.012

Valiantzas, J. D. (2013a). Simple ETo forms of Penman's equation without wind and/or humidity data. I: Theoretical development. J. Irrig. Drain. Engrg., $139(1), \quad$ 1-8. http://dx.doi.org/10.1061/(ASCE)IR.1943-4774.0000502

Valiantzas, J. D. (2013b). Simplified reference evapotranspiration formula using an empirical impact factor for Penman's aerodynamic term. J. Hydrol. Engrg., 18(1), 108-114. http://dx.doi.org/10.1061/(ASCE)HE.1943-5584.0000590

Ventura, F., Spano, D., Duce, P., \& Snyder, R. L. (1999). An evaluation of common evapotranspiration equations. Irrig. Sci., 18(4), 163-170. http://dx.doi.org/10.1007/s002710050058

Wai, N. M., Camerlengo, A., Wahab, A. K. A., \& Harun, S. (2004). Estimation of evaporation and evapotranspiration in Malaysia using Penman and Christiansen methods. Borneo Science, 15, 23-26.

Wright, J. L. (1982). New evapotranspiration crop coefficients. J. Irrig. Drain. Div., Am. Soc. Civ. Eng., 108(2), 57-74.

Yoder, R. E., Odhiambo, L. O., \& Wright, W. C. (2005). Evaluation of methods for estimating daily reference crop evapotranspiration at a site in the humid Southeast United States. Applied Engineering in Agriculture, 21(2), 197-202. http://dx.doi.org/10.13031/2013.18153

\section{Appendix}

Appendix 1. List of Abbreviations Used

$\Delta$ : slope of saturation vapor pressure with air temperature, $\mathrm{kPa} /{ }^{\circ} \mathrm{C}$.

$\gamma$ : psychrometric constant, $\mathrm{kPa} /{ }^{\circ} \mathrm{C}$.

$\varphi$ : latitude of site, radians.

ET: evapotranspiration rate, $\mathrm{mm} / \mathrm{h}$ or $\mathrm{mm} / \mathrm{d}$ or inches $/ \mathrm{d}$.

PET: potential ET rate, $\mathrm{mm} / \mathrm{h}$ or $\mathrm{mm} / \mathrm{d}$ or inches $/ \mathrm{d}$.

$\mathrm{ET}_{0}$ : reference evapotranspiration rate from a grass surface, $\mathrm{mm} / \mathrm{h}$ or $\mathrm{mm} / \mathrm{d}$ or inches $/ \mathrm{d}$.

$\mathrm{ET}_{\mathrm{sz}}:$ reference evapotranspiration rate from a standardized surface, $\mathrm{mm} / \mathrm{h}$ or $\mathrm{mm} / \mathrm{d}$.

$\mathrm{ET}_{\mathrm{c}}$ : crop evapotranspiration, $\mathrm{mm} / \mathrm{h}$ or $\mathrm{mm} / \mathrm{d}$.

u: monthly consumptive use (ET), inches/mon. or $\mathrm{mm} / \mathrm{mon}$.

U: seasonal consumptive use (ET), inches/season or $\mathrm{mm} / \mathrm{season}$.

$\mathrm{K}_{\mathrm{c}:}$ crop coefficient developed by FAO 56 method.

$\mathrm{k}$ : empirical crop coefficient for monthly period.

$\mathrm{K}$ : empirical crop coefficient for irrigation season or growing period.

$\mathrm{T}_{\mathrm{a}}$ : mean monthly/daily/hourly air temperature, ${ }^{\circ} \mathrm{C}$.

$\mathrm{T}_{\mathrm{F}}$ : mean monthly/daily/hourly air temperature, ${ }^{\circ} \mathrm{F}$.

$\mathrm{t}$ : difference between actual canopy temperature and canopy temperature in wet conditions, ${ }^{\circ} \mathrm{C}$.

$\mathrm{u}_{2}$ : wind speed at $2 \mathrm{~m}$ height, $\mathrm{m} / \mathrm{s}$.

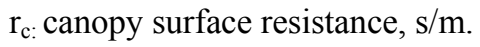

$r_{a}$ : aerodynamic resistance, $s / m$.

$\mathrm{r}_{1}$ : daily average stomatal resistance: $\mathrm{s} / \mathrm{m}$.

$\mathrm{r}_{\mathrm{i}}$ : climatological resistance, $\mathrm{s} / \mathrm{m}$.

$\mathrm{r}^{*}$ : climatic resistance, $\mathrm{s} / \mathrm{m}$.

RH: relative humidity, $\%$.

$\mathrm{R}_{\mathrm{n}}$ : net radiation, $\mathrm{MJ} / \mathrm{m}^{2} / \mathrm{d}$ or $\mathrm{MJ} / \mathrm{m}^{2} / \mathrm{h}$.

$\mathrm{R}_{\mathrm{s}}$ : incoming solar radiation, $\mathrm{MJ} / \mathrm{m}^{2} / \mathrm{d}$ or $\mathrm{MJ} / \mathrm{m}^{2} / \mathrm{h}$. 
Ra: extraterrestrial radiation, $\mathrm{MJ} / \mathrm{m}^{2} / \mathrm{d}$ or $\mathrm{MJ} / \mathrm{m}^{2} / \mathrm{h}$.

$\mathrm{e}_{\mathrm{a}}$ : actual vapor pressure, $\mathrm{kPa}$.

$\mathrm{e}_{\mathrm{s}}$ : saturation vapor pressure, $\mathrm{kPa}$.

$\mathrm{D}$ : vapor pressure deficit, $\mathrm{kPa}$.

$\mathrm{p}$ : monthly percentage of daytime hours of the year, \%.

f: monthly consumptive use (ET) factor.

F: sum of monthly consumptive use (ET) factors for the period.

i: heat index.

I: sum of the 12 monthly heat index $i$.

S: measured sunshine hours times 100 divided by the number of possible sunshine hours.

$\mathrm{K}_{\mathrm{RS}}$ : calibration coefficient.

TD: mean maximum minus mean minimum temperature, ${ }^{\circ} \mathrm{C}$.

$\mathrm{K}$ : dimensionless constant developed empirically from data analysis.

$\mathrm{C}$ : dimensionless coefficient related to climatic parameters.

G: soil heat flux, $\mathrm{MJ} / \mathrm{m}^{2} / \mathrm{d}$ or $\mathrm{MJ} / \mathrm{m}^{2} / \mathrm{h}$.

$\mathrm{f}(\mathrm{u})=$ wind speed function.

$\mathrm{J}$ : Julian day of the year.

$\lambda$ : latent heat of evaporation, $\mathrm{MJ} / \mathrm{kg}$.

$\rho$ : air density, $\mathrm{kg} / \mathrm{m}^{3}$

$\mathrm{C}_{\mathrm{p}}$ : specific heat capacity of air at constant pressure, $\mathrm{J} / \mathrm{kg} / \mathrm{K}$.

D: zero plane displacement height, $\mathrm{m}$.

hc: crop height, $\mathrm{m}$.

$\mathrm{z}_{\mathrm{m}}$ : height of wind measurements, $\mathrm{m}$.

$z_{h}$ : height of humidity measurements, $m$.

$\mathrm{z}_{\mathrm{om}}$ : roughness lenth governing momentum transfer, $\mathrm{m}$.

$\mathrm{z}_{\mathrm{oh}}$ : roughness length governing heat transfer.

k: von-Korman's constant $(0.41)$.

$\mathrm{U}_{\mathrm{z}}$ : wind speed at height $\mathrm{z}, \mathrm{m}$.

LAI: leaf area index, $\mathrm{m}^{2} / \mathrm{m}^{2}$.

$\mathrm{C}_{\mathrm{n}}$ : numerator constant that changes with reference type and calculation time step, $\mathrm{K} \mathrm{mm} \mathrm{s} \mathrm{M} / \mathrm{g} / \mathrm{d}$ or K mm $\mathrm{s}^{3} \mathrm{M} / \mathrm{g} / \mathrm{h}$.

$\mathrm{C}_{\mathrm{d}}$ : denominator constant that changes with reference type and calculation time step, s/m.

$\mathrm{W}_{\text {aero }}$ : empirical weighted factor.

Appendix 2. Shuttleworth Model

Shuttleworth (2006) developed an equation for crop coefficient $\left(\mathrm{K}_{\mathrm{c}}\right)$ which is as follows:

$$
K_{c}=\left[\frac{\frac{R_{c}^{50}}{u_{2}}+\frac{D_{50}}{D_{2}} r_{c l i m}}{\frac{302}{u_{2}}+\frac{D_{50}}{D_{2}} r_{c l i m}}\right]\left[\frac{(\Delta+\gamma) \frac{302}{u_{2}}+70 \gamma}{(\Delta+\gamma) \frac{R_{c}^{50}}{u_{2}}+\gamma\left(r_{s}\right)_{c}}\right]
$$

where,

$\mathrm{R}_{\mathrm{c}}{ }^{50}=$ aerodynamic coefficient for a crop of height $\mathrm{h}_{\mathrm{c}}$ at blending height of $50 \mathrm{~m}$;

$\mathrm{U} 2$ = wind speed at $2 \mathrm{~m}$ height; 
D50 = vapor pressure deficit at blending height of $50 \mathrm{~m}(\mathrm{kPa})$;

$\mathrm{D} 2$ = vapor pressure deficit at $2 \mathrm{~m}$ height $(\mathrm{kPa})$;

$\mathrm{r}_{\text {clim }}=$ climatological resistance $=\frac{\rho c_{p} D}{\Delta\left(R_{n}-G\right)}(\mathrm{s} / \mathrm{m})$.

$\left(r_{s}\right)_{c}=$ surface resistance of crop $(\mathrm{s} / \mathrm{m})$

The equation to calculate $\mathrm{R}_{\mathrm{c}}{ }^{50}$ in Equation (1) is given by:

$$
R_{c}^{50}=\frac{1}{(0.41)^{2}} \ln \left[\frac{\left(50-0.67 h_{c}\right.}{\left(0.123 h_{c}\right)}\right] \ln \left[\frac{\left(50-0.67 h_{c}\right.}{\left(0.0123 h_{c}\right)}\right] \frac{\ln \left[\frac{(2-0.08)}{0.0148}\right]}{\ln \left[\frac{(50-0.08)}{0.0148}\right]}
$$

The equation to calculate $r_{\text {clim }}$ in Equation (1) is given by:

$$
r_{\text {clim }}=\frac{208}{u_{2}}\left[\frac{\alpha\left[\Delta+\gamma\left(1+0.337 u_{2}\right)\right]}{\Delta+\gamma}\right]-1
$$

where, $\alpha$ is the Priestley-Taylor coefficient, which is equal to 1.26.

The equation to calculate $\left(\frac{D_{50}}{D_{2}}\right)$ in Equation (1) is given by:

$$
\left(\frac{D_{50}}{D_{2}}\right)=\left[\frac{(\Delta+\gamma) 302+70 \gamma u_{2}}{(\Delta+\gamma) 208+70 \gamma u_{2}}\right]+\frac{1}{r_{\text {clim }}}\left\{\left[\frac{(\Delta+\gamma) 302+70 \gamma u_{2}}{(\Delta+\gamma) 208+70 \gamma u_{2}}\right]\left[\frac{208}{u_{2}}\right]-\frac{302}{u_{2}}\right\}
$$

The equation to calculate surface resistance $\left(r_{s}\right)_{c}$, according to Shuttleworth is given by:

$$
\left(r_{s}\right)_{c}=\frac{r_{s}^{1}}{K_{c}^{F A O}}-r_{s}^{2}
$$

where, $\mathrm{K}_{\mathrm{c}}{ }^{\mathrm{FAO}}$ is the different $\mathrm{Kc}$ values of different crops published in FAO 56 document, $\mathrm{r}_{\mathrm{s}}{ }^{1}$ and $\mathrm{r}_{\mathrm{s}}{ }^{2}$ are given by:

$$
\begin{gathered}
r_{s}^{1}=\left(\frac{\frac{R_{c}^{50}}{u_{2}}+\left(\frac{D_{50}}{D_{2}}\right)^{\text {pref }}\left(r_{\text {clim }}\right)^{\text {pref }}}{\left.\frac{302}{u_{2}}+\left(\frac{D_{50}}{D_{2}}\right)^{\text {pref }}\left(r_{\text {clim }}\right)^{\text {pref }}\right) \times\left(\frac{\left(\Delta^{\text {pref }}+\gamma\right) \frac{302}{u_{2}}+70 \gamma}{\gamma}\right)}\right. \\
r_{s}^{2}=\frac{\left(\Delta^{\text {pref }}+\gamma\right)}{\gamma} \frac{R_{c}^{50}}{u_{2}}
\end{gathered}
$$

where, $\Delta^{\text {pref }}$ is the value of $\Delta$ calculated at temperature $\mathrm{T}^{\text {pref }}\left(\mathrm{kPa} /{ }^{\circ} \mathrm{C}\right), \mathrm{T}^{\text {pref }}$ being the air temperature when the value of $\mathrm{K}_{\mathrm{c}}^{\mathrm{FAO}}$ was derived $\left({ }^{\circ} \mathrm{C}\right)$ and $\left(\frac{D_{50}}{D_{2}}\right)^{\text {pref }}$ is the value of $\left(\frac{D_{50}}{D_{2}}\right)$ at $\mathrm{T}^{\text {pref }}$.

$\left(\mathrm{r}_{\mathrm{clim}}\right)^{\text {pref }}$ can be obtained from Equation (3) as:

$$
\left(r_{\text {clim }}\right)^{\text {pref }}=104\left[1.26 \frac{\left[\Delta^{\text {pref }}+1.67 \gamma\right]}{\Delta^{\text {pref }}+\gamma}\right]-1
$$

\section{Copyrights}

Copyright for this article is retained by the author(s), with first publication rights granted to the journal.

This is an open-access article distributed under the terms and conditions of the Creative Commons Attribution license (http://creativecommons.org/licenses/by/3.0/). 